\title{
Enhancing Communicative Competence in English through Conscious Efforts and Good Reading Culture: A Study of some Universities in Northern Nigeria
}

Mudassir Ismaila Moyi*, Sani Galadima Department of English and Literature, Federal University Gusau, Zamfara State, Nigeria

Article History

Received: 29.09.2020

Accepted: 18.10 .2020

Published: 30.10 .2020

Journal homepage: https://www.easpublisher.com/easjehl

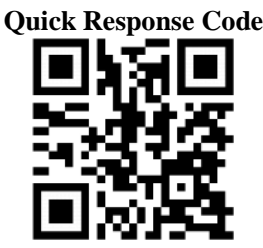

Abstract: The study looks at how good reading culture and conscious efforts to speak the English language in enhancing the communicative competence of Nigerian University Students. The study uses quantitative techniques where questionnaires were used to get responses from four Universities spread across the Northern part of the Country. The study adopted stratified sampling techniques were 50 students each undergoing various courses of study and in their different age groups were chosen from Federal University Gusau, Zamfara State; University of Ilorin, Kwara State; North-West University Kano (also renamed to Maitama Sule University), Kano State and Nasarawa State University Keffi, Nasarawa State. The choice of two state universities and two federal universities from each of the two zones selected is done to make sure that the responses reflect happening in those areas. The findings were tabulated in simple percentages while charts were used to show pictorial results. The study, however, established that there is a greater number of students who testify to the fact that they either seldom engage in reading and other speaking activities or they never engaged in such activities at all. This habit may downplay their communicative capabilities. It is recommended that teachers of language should encourage students under their care to imbibe a reading culture as it boosts learners' vocabularies, hence their proficiency in spoken language

Keywords: Communicative competence, reading, University Students, English language.

Copyright ( 12020 The Author(s): This is an open-access article distributed under the terms of the Creative Commons Attribution 4.0 International License (CC BY-NC 4.0) which permits unrestricted use, distribution, and reproduction in any medium for non-commercial use provided the original author and source are credited.

\section{INTRODUCTION}

Communicative competence is central to every second language situation, this is because the secondlanguage speaker has inhibitions and limitations as to the extent to which his abilities in the target language can be developed. Part of the reason being that a second language is always acquired only later in life after the properties of a first language may have been internalized. If this is the case, it means that levels of attainment of proficiency would not be the same for the first and second language speakers.

Moody [1] says second-language teaching aims to assist the development of the same or similar kind of ability or proficiency in the language being learned. There is no doubt that this is what second language teachers strive to develop in their students, who are learners.

There are four skills in which learners of any language must attain some level of proficiency in them before he can be adjudged competent in that language. These skills are listening, speaking, reading, and writing. While listening and reading are receptive, speaking and writing are productive. It may be fairly possible to measure one's competence in a language by one's reading abilities, but the same is not always the case for listening. There are restraints as to how much we can observe of a learner's competence through the receptive skills of listening and reading. Therefore, the productive skills of speaking and writing are better analyzed in terms of determining the level of competence of users. But none of them will be neglected because a deficiency in one affects proficiency in the other - the four make up a connected web.

Hedge [2] believes that it is impossible to conceive of a person being communicatively competent without being linguistically competent. For communication to be successful, learners need to know the appropriate social conventions. Some previous studies highlight some factors affecting speaking skills. An article titled: Difficulties in Speaking English (2014) cited in Waandja [3] maintains that most English second language learners (ESLL), who are not accustomed to English-speaking environment are 
frequently challenged with English-spoken communication.

Attempts to measure what the level or amount of linguistic knowledge a speaker must possess to be able to communicate competently have not been very successful. But scholars like Savignon and Schulz [4] have written about the minimum level of what would enable a learner or speaker of a second language to get his meaning across, to do the things he wishes to do in the second language and to say what he wants to say. Van Ek [5] proposes what he called the 'threshold level'. It is however controversial, since measuring such a level is difficult. But what is important in his proposition is that the general objective for the 'threshold level' for the second language is "that learners will be able to survive (linguistically speaking) $\ldots$ in everyday conversations and to establish and maintain social contacts" (p. 24-25).

\section{Statement of the problem}

Effective communication is essential in every language situation - be it a first or second language environment. What guarantees this, of course, is proficiency in the use of the language in question (E.g English Language in this case). When effective communication fails to be realized, the intended message may be misunderstood. As a result, the communication breaks.

Confucius, the legendary philosopher, quoted in [6] summarizes it thus:

If the language is not correct, then what is said is not what is meant; if what is said is not what is meant, then what ought to be done remains undone; if this remains undone, morals and arts deteriorate;... Hence there must be no arbitrariness in what is said. This matters above everything.

This underscores the importance of effective communicative competence in human society. For this to be achieved, certain linguistic abilities have to be internalized by the learners of a given language.

Teachers of English at various levels as well as employers of labour complain passionately that the standard of English has fallen considerably in Nigeria. The undeniable evidence for this is the current performance of students who write English in WAEC, NECO, and JAMB examinations as well as in different job interviews. For years, these examining bodies decry the abysmally poor performance of students in English. Even at the university level, almost the same challenges are encountered. There is no doubt that this is attributable to many other factors; part of which there is a near absence of reading culture and refusal to make a conscious effort in learning the English Language.
Baldeh [7] argued in his book 'Better English Language Learning and teaching' that..." the purpose of language learning in the sense of L2 is the development of learner's communicative competence..."(P. 59). However, until now, language teaching and learning in Nigeria has remained grammar-based. Teachers strive to make their students learn the grammar of English intending to make students communicate competently in both the spoken and written media of the language. But the question is: since English language teaching and learning became grammar-based in Nigeria, has the standard remained? or changed? If the present threat facing the learning of the English language in Nigeria is to be properly addressed, then we must have a rethink of the present approaches and make recourse to communicative approaches, for in the final analysis, the important thing is whether the learner has acquired the necessary tools of the language which will enable him to perform his expected multifarious roles effectively in the community of the speakers of the target language [7].

Having painted the horrific picture of the situation, the research, therefore, sets to identify the causes behind this poor communicative competence with a view to proffering solutions to it.

\section{OBJECTIVES OF THE STUDY}

The main interest of this work is to find out the role of proper reading culture and conscious effort in speaking the English Language even with mistakes in the attainment of communicative competence. Summarily, this study aims to achieve the following objectives:

1. To highlight possible ways to reduce problems of communicative incompetence among university students in Northern Nigeria;

2. To identify how proper reading culture helps in boosting speakers' communicative competence;

3. To see how conscious efforts in speaking English can serve as "comprehensible input" for second language learning;

4. To recommend efforts to be adopted by teachers, policymakers, administrators, and students to arrest the ugly trend.

\section{REVIEW OF RELEVANT LITERATURE Communicative Competence}

Communicative competence according to Opara [8] deals with "performance, that is, the speaker's ability to understand and use utterances appropriate to different contexts. It means fluency in oral and written communication".

Yano [9] says that "successful language use for communication presupposes the development of communicative competence in the users of that language which is constrained by the socio-cultural norms of the society where the language is used. 
Communicative competence is sine qua non to students' academic success because proficient speaking opens the door to success while writing tests students' linguistic ability. For students to attain academic peak, mastery of English language knowledge is important. Everyday interactions demand demonstration of mastery of linguistics knowledge.

Canale and Swain [10] defined communicative competence in the context of second language teaching. According to them, it is "a synthesis of knowledge of basic grammatical principles, knowledge of how language is used in social settings to perform communicative functions and knowledge of how utterances and communicative function can be combined according to the principle of discourse".

Widdowson [11] in his attempt to clarify the concept of communicative competence, made a distinction between grammatical competence and capacity. His definition, which he applied insight gained from pragmatic and discourse analysis, he defines competence (i.e communicative competence) in terms of the knowledge of linguistic and sociolinguistic conventions. Under capacity, which he often referred to as procedural or communicative capacity, he understood it to mean the ability to use knowledge as a means of creating meaning in a language. According to him, the ability is not a component of competence.

Urrutia and Vega [12] maintain that a shortage of words by learners is another possible cause of learners speaking difficulty, where they stated that there are learners who need to express their ideas in a second language, but often find themselves without linguistics resources to do so. Carnagie [13] also believes that the chief cause of fear to speak in public simply is that one is not accustomed to speaking in public.

\section{Reading and Reading Culture}

Wallace [14] says "books yield their best to you if you read them at the age at which each particular masterpiece can ideally be chewed and digested". Everyday reading consists of individuals' reading activities for a variety of purposes, such as relaxation or information. He believes that from middle childhood through adulthood, reading becomes a major component of studying, and much information learned through studying is initially acquired threading.

Wille [15], Cited in Oyewole [16] asserts that 'reading' is the act of getting meaning from printed or written words, which is the basis for learning and one of the most important skills in everyday life. Unoh [17], further explain that reading is usually associated with books as only the written words provide a complete picture of the act of reading. It means that through reading, the individual can build or fix things, enjoy stories, discover what others believe, and develop ideas of beliefs of their own. Ogbonna [18] also maintained that one should be able to read. Reading according to him is the foundation of literacy. However, reading always has a purpose. It could be for pleasure, for learning and survival.

A study carried out 'Reading for Change 2002' showed that reading enjoyment is more important for children's educational success than the family's socioeconomic status. Thus, the frequent admonition for children to 'read', reading makes sense in that extensive reading promotes fluency, vocabulary, and background knowledge.

\section{Grammatical and Linguistic Competence}

Chomsky [19] made a distinction between 'competence' and 'performance.' The former is the linguistic knowledge of the idealized native speaker, an innate biological function of the mind that allows individuals to generate the infinite set of grammatical sentences that constitutes their language, and the latter is the actual use of language in concrete situations.

Hymes [20] in reaction to Chomsky's [19] notion of 'Linguistic competence' coined 'Grammatical competence' to mean the intuitive functional knowledge and control of the principles of language usage. He also observed that

... a normal child acquires knowledge of sentences not only as grammatical but also as appropriate. He or she acquires competence as to when to speak, when not, and as to what to talk about with whom, when, where, in what manner. In short, a child becomes able to accomplish a repertoire of speech acts, to take part in speech events, and to evaluate their accomplishment by others Hyme [20].

Some scholars believe that a learner cannot be communicatively competent without being linguistically competent [2]. Pillar [21] adds that linguistic competence refers to the mastery of knowledge of the language code itself. This involves controlling the formal organization of the language for producing or recognizing correct sentences and organizing them to form texts. Linguistic competence includes the rules of word formation and vocabulary (lexicon), pronunciation (phonology), and sentence formation (syntax)".

In other words, a language user needs to use the language not only correctly (based on linguistic competence) but also appropriately (based on communicative competence). This approach does not diminish the importance of learning the grammatical rules of a language. In fact, it is one of the four components of communicative competence: linguistic, sociolinguistic, discourse, and strategic competence. 
Linguistic competence is the knowledge of the language code, i.e. knowledge of grammatical rules and vocabulary development. The knowledge of the sounds systems, pronunciation and arrangement of sounds to forms words and utterances (i.e. phonetics \& Phonology), the formation of words utilizing e.g. inflection and derivation (i.e. morphology), the rules that govern the combination of words and phrases to structure sentences (i.e. syntax), and the way that meaning is conveyed through language (i.e. semantics). Sociolinguistic competence, on the other hand, is the knowledge of socio-cultural rules of language use, i.e. knowing how to use and respond to language appropriately. The appropriateness depends on the setting of the communication, the topic, and the relationships among the people communicating. Discourse competence also is the knowledge of how to produce and comprehend oral or written texts in the modes of speaking/writing and listening/reading respectively. Thus, discourse competence deals with organizing words, phrases, and sentences to create conversations, speeches, poetry, email messages, newspaper articles, etc. While Strategic competence is the ability to recognize and repair communication breakdowns before, during, or after they occur. These strategies may be requests for repetition, clarification, slower speech, or the usage of gestures, taking turns in conversation, etc.

\section{Theories Second Language Acquisition}

Language acquisition does not require extensive use of conscious grammatical rules and does not require a tedious drill [22].

Acquisition requires meaningful interaction in the target language (i.e English) - natural communication - in which speakers are concerned not with the form of their utterances but with the messages they are conveying and understanding. The best method is to allow the supply of comprehensible and communicative inputs in low anxiety situations, containing messages that are of interest to the students.

\section{Krashen's Theory of Second-language Acquisition}

Stephen D. Krashen is a specialist in linguistic with a specialization in theories of language acquisition and development, he proposes five main hypotheses on second language acquisition. The Krashen hypotheses are of (1) Acquisition-Learning (2) Monitor (3) Natural Order (4) Input and (5) Affective Filter hypothesis.

Based on the Acquisition-Learning hypothesis, Krashen asserts that acquisition and learning are two independent systems of second language performance. Acquisition, according to Krashen, is the product of a subconscious process very similar to the process children undergo when they acquire their first language. It requires meaningful interaction in the target language - natural communication - in which speakers are concentrated not in the form of their utterances, but in the communicative act (that is the message they are conveying and understanding). In this process, speakers are aware of the fact that they are acquiring language. They are not aware of the rules for the language they acquired inductively or unconsciously. However, they develop a feeling of what sounds right or wrong in the target language. While learning is the product of formal instruction and it comprises a conscious process, which results in conscious knowledge about the language, and involve also knowledge of grammatical rules, etc. Krashen, however, believes that acquisition is more important than learning.

The Monitor hypothesis according to Krashen involves an explanation of the relationship between acquisition and learning and defines an influence of the latter on the former. Monitoring involves a practical result of the learned grammar. Krashen further asserts that the acquisition system is the utterance initiator, while a learning system performs the role of an editor or monitor. The monitor acts in planning, editing, and correction function when three specific conditions are met: that is, (a) the second language learner has sufficient time at his/her disposal, (b) he/she focuses on a form or thinks about correctness and (c) he/she knows the rules. The role of monitor is minor, it is aimed at correcting any deviation from normal speech and gives it a more polished appearance. However, it is often difficult to use monitor correctly since language rules are extremely complex.

Krashen suggests the variation in the use of monitor by individual language learners. He then distinguishes between those who use monitor all the time (over-users), those who have not learned or prefer not to use their conscious knowledge (under-users), and those who use it appropriately (optimal users). He added that an evaluation of the person's psychological profile can help to determine what group they belong to. Usually, extroverts are under-users, while introverts and perfectionists are over-users. Lack of self-confidence is frequently related to the over-use of the monitor.

The Natural Order hypothesis is based on research findings $[23-25,22]$ which suggested that the acquisition of grammatical structure follows a natural, predictable order. In other words, language acquisition occurs in a predictable and universal order for both L1 \& L2. For a given language (E.g English), some grammatical structures tend to be acquired early while others late. For example, the -ing form (present continuous) will be acquired early on and almost certainly before the $-s$ inflection in the third person singular present (she likes, he eats, etc). Krashen also believes that this order seemed to be independent of the learners' age, mother tongue background, conditions of exposure, and although the agreement between individual acquirers was not always $100 \%$ in the 
studies, there were statistically significant similarities that reinforced the existence of a Natural Order of language acquisition.

The Input hypothesis is Krashen's attempt to explain how the learner acquires a second language. According to Krashen, language can be acquired only when learners are exposed to input (written or spoken language) that is comprehensible to them. Comprehensible input is necessary but also sufficient condition for language acquisition to take place. It requires no effort on the part of the learner. This hypothesis, therefore, concerns the acquisition not learning. This hypothesis asserts that the learner improves and progresses along with the 'natural order' when he/she receives second language 'input' that is one step beyond his/her current stage of linguistic competence. For example, if a learner is at a stage ' $a$ ', then acquisition takes place when he/she is exposed to 'Comprehensible Input' that belongs to level 'a +1 '. Since not all learners will be at the same linguistic level at the same time, Krashen suggests that natural communicative input is crucial to designing a syllabus, ensuring in this way that each learner will receive some ' $\mathrm{i}+1$ ' input that is appropriate for his/her current stage of linguistic competence. When that happens, acquisition takes place effortlessly and involuntarily.

The Affective Filter hypothesis, on the other hand, suggests that many 'affective variables' play a facilitative, but non-causal, role in second language acquisition. These variables include motivation, selfconfidence, and anxiety. Krashen [26] claims that learners with high motivation, self-confidence, a good self-image, and a low level of anxiety are better equipped for success in second language acquisition. Low motivation, low self-esteem, and debilitating anxiety can combine to 'raise' the affective filter and form a 'mental block' that prevents comprehensible input from being used for acquisition. In other words, when the filter is 'up' it impedes language acquisition. Therefore, Learners with a low affective filter will not only be efficient language acquirers of the comprehensible input they receive, but they are also more likely to interact with others, unembarrassed by making mistakes and thus, increase the amount of that input.

\section{The Creative Construction Hypothesis of Second Language Learning (Interlanguage Theory)}

This hypothesis countered the behaviorists believe that second language learning is a process of habit formation and that the major obstacle to learning a second language is the mother tongue interference. Researchers [23], however, set out to show that learners of a second language as well as first language are endowed with an innate mechanism for processing and creating their internal grammar. The grammar that learners create is called their 'interlanguage' (i.e language that is in the continuum between mother tongue and the target language) [27] or 'transitional competence', a competence which is in the state of transition, developing in the direction of the target language [28]. However, it does not become identical with the target language, as some non-target features become fossilized in the learner's grammar. In this theory (creative construction, otherwise called 'interlanguage theory') it is claimed that many of these innate mechanisms are specific to language learning rather than general cognitive nature, since the input does not contain enough evidence for general cognitive mechanisms to work on. The input serves as a trigger to activate the mechanisms.

Some processes influence the creation of interlanguage:

- Language Transfer: learners' fall back to his first language to help create their own language system. It sometimes refers to a mistake, but it is a process that all second language learners go through, particularly when the second language share a wide range of structure with the mother tongue. A transfer is a powerful process that can take the learner deep into the new system [29].

- Overgeneralization: learners use rules from the second language in a way that the native speakers would not. E.g a learner would say 'I buyed a shirt' or 'He goed home' overgeneralizing the use of 'ed' to form past tense form. According to [30], the ability to go beyond the information given, inexperience, and make overgeneralization, which can be used to understand and create a new form of experience, is fundamental to learning.

- Simplification: this third process of interlanguage, unlike the two earlier mentioned, is reductionist. In this stage, language learners omit elements that are redundant and produce something similar to 'telegraphic speech' found in early mother tongue acquisition. For example, 'daddy travelled, mummy asleep' spoken by an English child in learning English. Or somebody that paid for a cup of tea in advance in a canteen and had gone to a wrong counter to collect it, the cashier may correct him with a gesture and Sir!.....tea there or Photocopier broken said by a Chinese native speaker in Hong Kong, etc. 


\section{The interaction Hypothesis}

The interaction hypothesis by Michael Long [31] is a development from the 'input hypothesis'. Long believes that the pre-requisite for learning is still seen as comprehensive input, however, this hypothesis argued that the comprehensive input is more likely to occur under social interaction. As a result, it is more likely that the input will be tuned to the current level of competence of the individual learner and thus become 'intake' which is available for learning. Researchers believed that increased opportunities for negotiation are likely to lead to increased comprehension. Likewise, they also studied a kind of classroom interaction task that is most likely to lead to the negotiation of meaning.

\section{Output Hypothesis}

Second language learners usually go through a 'silent period' when they listen and respond but do not produce language themselves. Nonetheless, they develop the knowledge of the language which later serves as a basis for their language production. The output hypothesis argued that input alone is not sufficient, output also plays a significant role in language acquisition [32]. The need to speak or write makes learners pay attention to some aspects of grammar which they would not need for comprehension purposes alone, thus it will make them notice gaps in their knowledge. The hypothesis, therefore, allows learners to make a hypothesis about how the grammatical systems work and (when meanings are negotiated) they get feedback about whether these hypotheses are correct.

\section{METHODOLOGY}

To achieve the objectives set forth for this study, a survey research design was adopted in this study. The target population for this research will constitute of undergraduate students studying in some four universities across the North West and North
Central parts of the Country. The population will consist of 200 students, 50 each from the University of Ilorin, Kwara State; Nasarawa State University, Lafia, Nasarawa State; Northwest University Kano, Kano State, and Federal University Gusau, Zamfara State. The spread of the research area will help the researchers to get as much input as possible on the problem at hand. However, based on the expected nature of the population, the main sampling technique to be employed to determine the sample size will be the stratified random sampling technique. This would be used to ensure an equitable representation of the sample population. These 50 students to be chosen from each university will consist of both genders (male and female). For this research, questionnaires will be administered to the selected students where questions related to respondents' reading culture as well as his conscious efforts in ensuring proficiency in the English Language would be asked.

The data collected will be correlated to show the advantage of good reading culture towards attaining a communicative competence in the English Language. Equally, the study will also establish how conscious activities in speaking helps in language acquisition/learning processes. The data will then be tabulated based on the number and percentages of the different responses.

\section{Data Presentation and Analysis Demographic Data}

There are demographic data of the respondents collected to identify with the respondents. The demographic data the researchers consider very important are: (a) the sex of the respondents (b) the field of study of the respondents (c) the geographical area of the respondents and finally (d) the age group of the respondents. This data is very necessary considering the topic at hand.

Gender Distribution of Respondents

\begin{tabular}{|l|l|l|}
\hline FUGUS & Male 27 (54\%) & Female 23 (46\%) \\
\hline University of Ilorin & Male 32(64\%) & Female 18 (36\%) \\
\hline Northwest University Kano & Male 22 (44\%) & Female 28 (56\%) \\
\hline Nasarawa State University Keffi & Male 16 (41\%) & Female 23 (59\%) \\
\hline
\end{tabular}

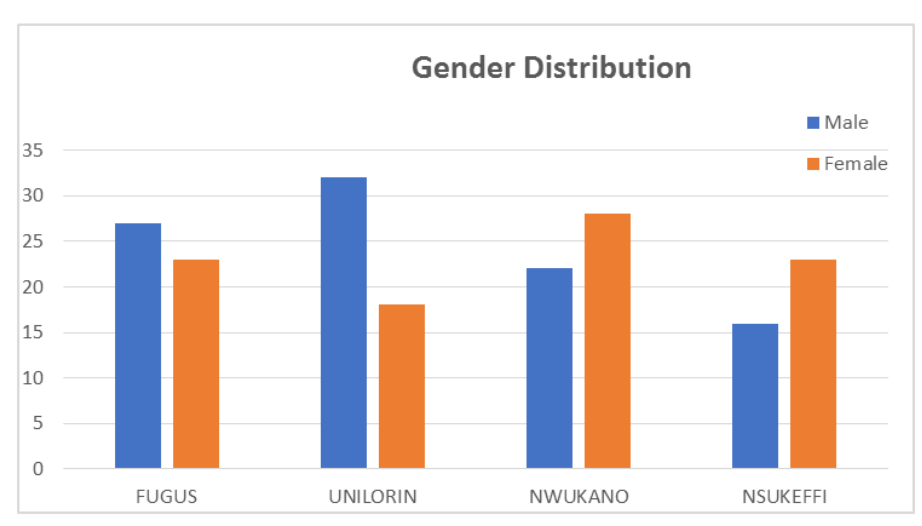




\section{FUGUS}

Distribution by Field of Study

Sciences: 27 (54\%); Social \& Mgt Sci.: 10 (20\%); Arts: 11 (22\%); Others (Education): 2 (4\%)

University of Ilorin

Sciences: 14 (28\%); Social \& Mgt Sci 8 (16\%); Arts 19 (38\%); Engineering. 7 (14\%); Medical \& Allied Sciences 1 (2\%); UNIDENTIFIED $1(1 \%)$

Northwest University Kano

Sciences: 8 (16\%); Social \& Mgt Sci. 8 (16\%); Arts 22 (44\%); Others (Education) 12 (24\%)

Nasarawa State University Keffi

Sciences: 0; Social \& Mgt Sci.: 0; Arts: 38 (97.4\%); Engineering: 1 (2.6\%)

Summary of responses across all the Universities

Sciences: 49 (25.9); Social \& Mgt Sci.: 26 (13.8\%); Arts: 90 (47.6); Engineering: 8 (4.23\%); Medical and Allied

Courses: 1 (0.53\%); others (Educ.) 12 (7.4\%) Unspecified responses: $1(0.53 \%)$

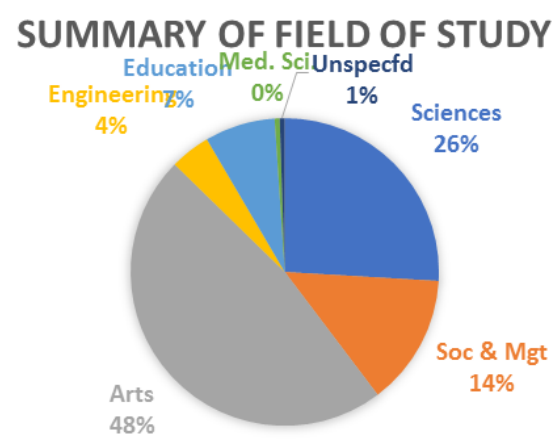

Distribution by Geographical Area

\begin{tabular}{|l|l|}
\hline FUGUS: & NW: 42 (84\%); NE: $0(0 \%) ;$ NC: $8(16 \%)$ \\
\hline University of Ilorin: & NW: 0; NE: 0; NC: $50(100 \%)$ \\
\hline Northwest University Kano: & NW: 40 (80\%); NE: $2(4 \%) ;$ NC: $4(8 \%)$; Unsppecified: $2(4 \%)$ \\
\hline Nasarawa State University Keffi: & $\begin{array}{l}\text { NW: } 3(7.7 \%) ; \text { NE: } 3(7.7 \%) ; \text { NC: } 31(79.5 \%) ; \text { Unspecified: } 2 \\
(5.12 \%)\end{array}$ \\
\hline Summary of all responses across all the four (4) universities \\
\hline NW: 85 (45\%); NE: 5 (2.6\%) \& NC: 93 (49.2\%); Unspecified responses: $6(3.2 \%)$ \\
\hline
\end{tabular}

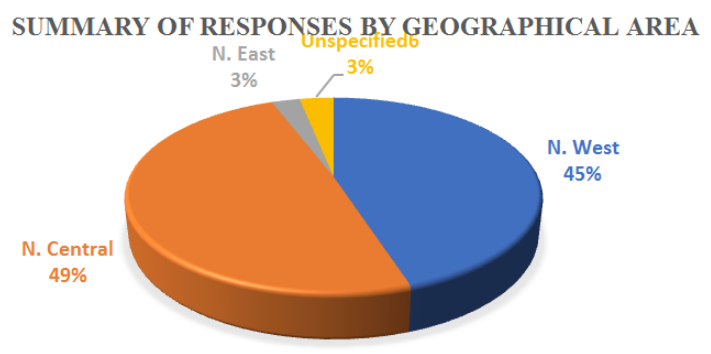

\section{FUGUS}

University of Ilorin

North-West University Kano

Nasarawa State University Keffi

Summary of all responses of age group across all Universities
Distribution by Age Group

18-25: 39 (78\%); 26-30: 9 (18\%); 36-40: 1 (2\%); Unspecified age: 1 $(2 \%)$

18-25: 39 (78\%); 26-30: $10(20 \%) ; 31-35: 1(2 \%)$

18-25: 27 (54\%); 26-30: 16 (32\%); 31-35: 5 (10); 36-40: 1 (2\%); Unspecified age group: $1(2 \%)$

18-25: 33 (84\%); 26-30: 5 (12.8\%); 31-35: 1 (2.6\%)

18-25yrs: 138 (73\%); 26-30yrs: 40 (21.2\%); 31-35yrs: 7 (3.7\%); 36-

40yrs: 2 (1.1\%); Unspecified age group: $2(1.1 \%)$ 


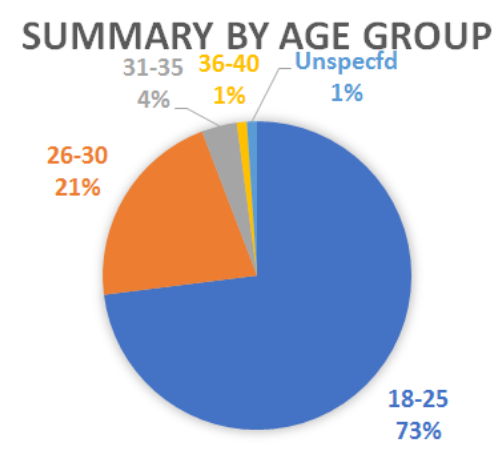

\section{DATA PRESENTATION AND ANALYSIS}

The questionnaire is divided into two (2) parts, with each part containing six (6) questions, making a total of twenty-four (12) questions. The options out of which a respondent can indicate his responses are in the scale of whether or not the item of the question is introduced. The options are: Never Introduced (NE); Seldom Introduced (SE); Often Introduced (OI) and Always Introduced (AI). The different parts of the questionnaire which the research sought to digest involve (1) reading activities that could enhance students' vocabulary as well as speaking ability and (2) any conscious activity that helps boost students' speaking habits.

Part One (1): Reading Activities that could Enhance Students' Vocabulary Development as well as their Speaking Ability

\section{Federal University Gusau}

Below is the summary of all responses to the six questions in this part from Federal University Gusau, Zamfara State, Nigeria

\begin{tabular}{|c|c|c|c|c|}
\hline NI: 07 (14\%) & SI: $07(14 \%)$ & OI: $09(18 \%)$ & AI: $25(50 \%)$ & ABS: $02(4 \%)$ \\
\hline \multicolumn{5}{|c|}{ 2. Reading of Science Fictional materials } \\
\hline NI: $09(18 \%)$ & SI: $06(12 \%)$ & OI: $11(22 \%)$ & AI: $19(38 \%)$ & ABS: $05(10 \%)$ \\
\hline \multicolumn{5}{|c|}{ 3. Reading of literary texts that relate to students' course of study (recommended literary texts) } \\
\hline NI: $10(20 \%)$ & SI: $06(12 \%)$ & OI: $12(24 \%)$ & AI: $20(40 \%)$ & ABS: $02(4 \%)$ \\
\hline \multicolumn{5}{|c|}{$\begin{array}{l}\text { 4. Reading of literary texts not related to students' course of study, but for the beauty of the materials c } \\
\text { vocabulary development }\end{array}$} \\
\hline NI: $10(20 \%)$ & SI: $04(8 \%)$ & OI: $17(34 \%)$ & AI: $16(32 \%)$ & ABS: $03(6 \%)$ \\
\hline \multicolumn{5}{|c|}{ 5. Regular reading of periodicals (e.g newspapers, magazines, short stories, etc) } \\
\hline NI: $07(14 \%)$ & SI: $09(18 \%)$ & OI: $15(30 \%)$ & AI: $17(34 \%)$ & ABS: $02(4 \%)$ \\
\hline \multicolumn{5}{|c|}{$\begin{array}{l}\text { 6. Reading of inspiring stories of distinguished personalities (autobiographies, biographies, diaries an } \\
\text { memoirs, etc) }\end{array}$} \\
\hline NI: $12(24 \%)$ & SI: $08(16 \%)$ & OI: $13(26 \%)$ & AI: $15(30 \%)$ & ABS: $02(4 \%)$ \\
\hline $55(18.33 \%)$ & $40(13.33 \%)$ & $77(25.67 \%)$ & $112(37.33 \%)$ & $16(5.33 \%)$ \\
\hline
\end{tabular}

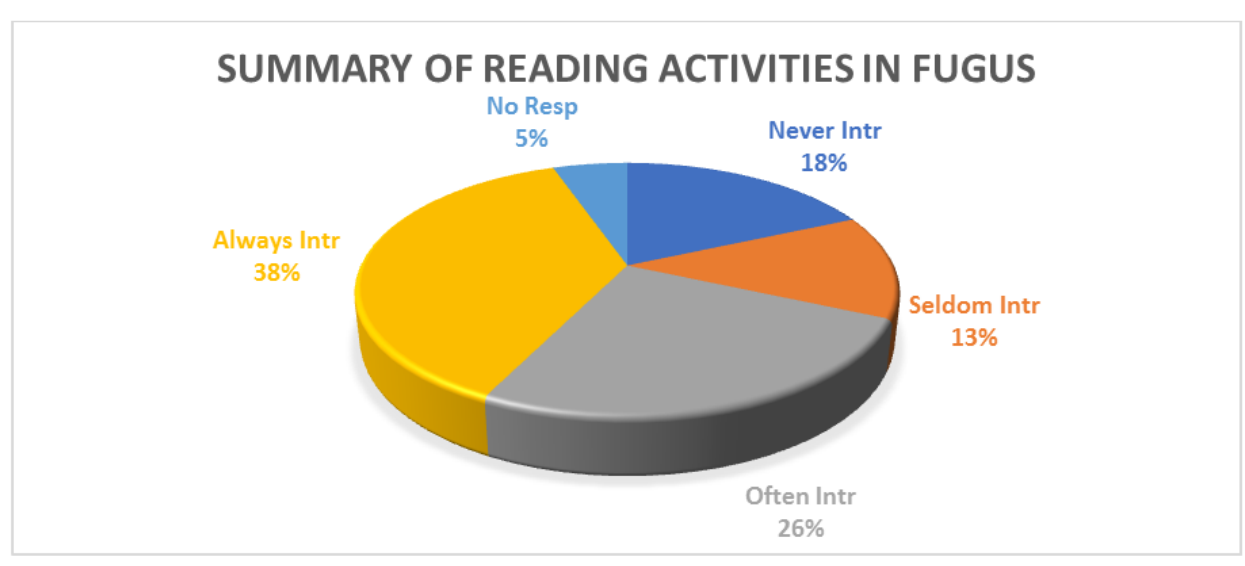


In Federal University Gusau, the responses show that students who testify that they were always introduced to reading culture lead with $38 \%$ of the total responses. They were followed by those that responded that the items under this category are often introduced. The two lead responses, always $38 \%$ and often $26 \%$, if it truly reflects the current reality, point to the fact that students in this part are expected to perform better when it comes to communicative competence. This is supported by Urrutia and Vega [12] when they assert that a shortage of words is the major cause of poor speaking ability. This can be arrested by imbibing a good reading habit.

University of Ilorin

\begin{tabular}{|c|c|c|c|c|}
\hline NI: $19(38 \%)$ & SI: $02(4 \%)$ & OE. $10(20 \%)$ & $10(2007$ & \\
\hline \multicolumn{5}{|c|}{ 2. Reading of Science Fictional materials } \\
\hline NI: $15(30 \%)$ & SI: $17(34 \%)$ & OI: $09(18 \%)$ & AI: $09(18 \%)$ & ABS: \\
\hline \multicolumn{5}{|c|}{ 3. Reading of literary texts that relate to students' course of study (recommended literary texts) } \\
\hline NI: $09(18 \%)$ & SI: $06(12 \%)$ & OI: $13(26 \%)$ & AI: $22(44 \%)$ & ABS: \\
\hline \multicolumn{5}{|c|}{$\begin{array}{l}\text { 4. Reading of literary texts not related to students' course of study, but for the beauty of the materials or vocabulary } \\
\text { development }\end{array}$} \\
\hline NI: $07(14 \%)$ & SI: $15(30 \%)$ & OI: $15(30 \%)$ & AI: $13(26 \%)$ & ABS: \\
\hline \multicolumn{5}{|c|}{ 5. Regular reading of periodicals (e.g newspapers, magazines, short stories, etc) } \\
\hline NI: $03(10 \%)$ & SI: $14(28 \%)$ & OI: $15(30 \%)$ & AI: $17(34 \%)$ & ABS: $01(2 \%)$ \\
\hline \multicolumn{5}{|c|}{ 6. Reading of inspiring stories of distinguished personalities (autobiographies, biographies, diaries and memoirs, etc) } \\
\hline NI: $10(20 \%)$ & SI: $11(22 \%)$ & OI: $09(18 \%)$ & AI: $20(40 \%)$ & ABS: \\
\hline $63(21 \%)$ & $65(21.67 \%)$ & $71(23.67 \%)$ & $100(33.33 \%)$ & $01(0.33 \%)$ \\
\hline
\end{tabular}

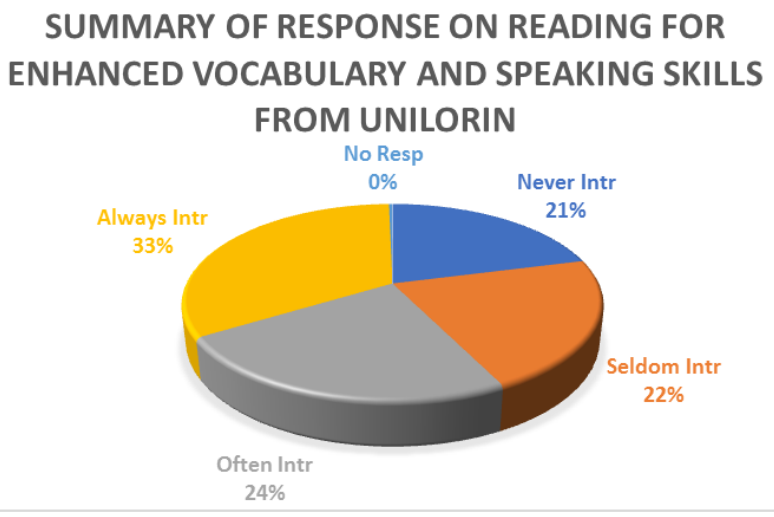

In the University of Ilorin also, the responses show students that testify to having items under this category always introduced leading with $33 \%$ followed also by those that testified that those same items are often introduced. Like in FUGUS, there is a good expectation that students in this part will perform well in terms of speaking ability as asserted by Odiba [33] who believes that reading increases knowledge and awareness and that in turn provides a backup of information which reduces ignorance, enhance literacy and communication.

North-West University Kano

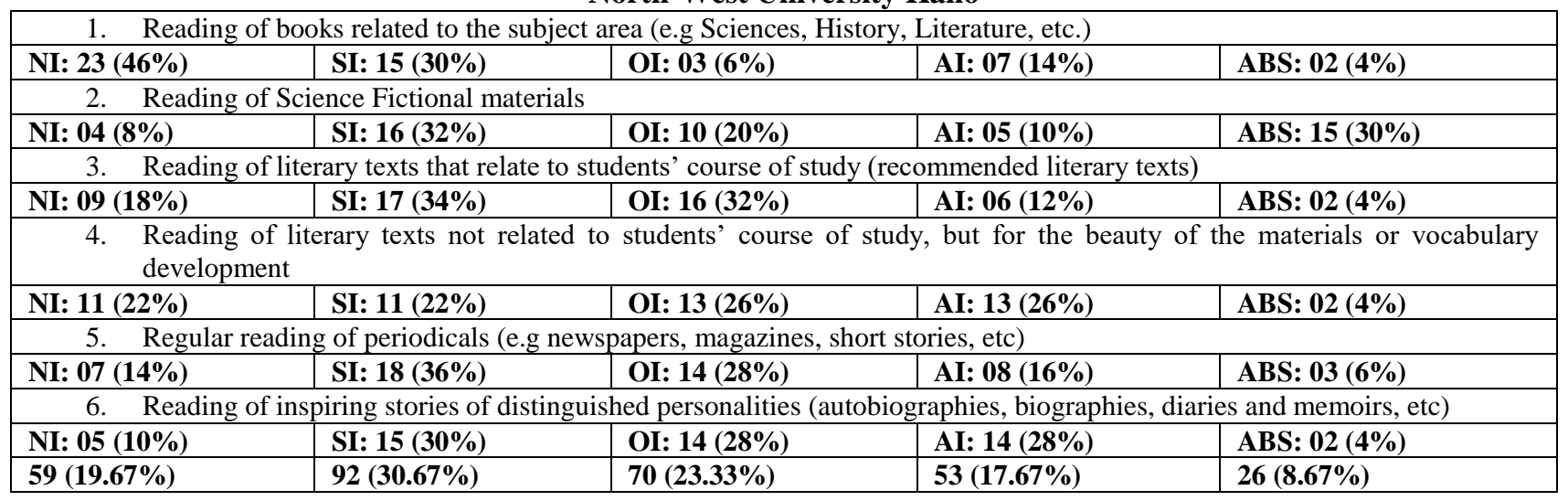




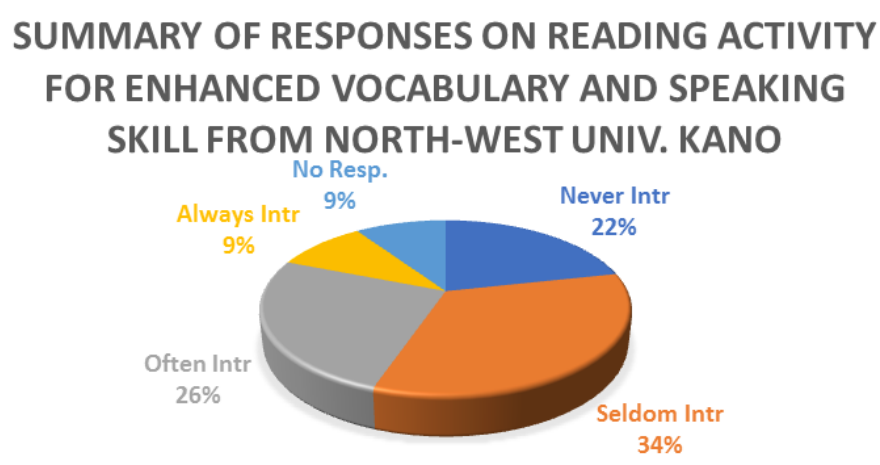

In the North-West University Kano (also known as Yusuf Maitama Sule University), the study shows that respondents who testify that the items in this category are seldom introduced to them lead with $34 \%$ they were followed by those who testify that the items were often introduced $26 \%$. These two categories of responses indicate that even though there is quite a good number of activities that promote reading culture, but it is not always that such activities are carried out. This confirms the fact that students in this part may not likely be competent when it comes to proficiency in speaking the English Language. This is because an English philosopher Francis Bacon (1561-1626) once said that while speaking makes a ready man and writing, an exact man, reading makes a full man.

Nasarawa State University Keffi

\begin{tabular}{|c|c|c|c|c|}
\hline NI: $02(5.12 \%)$ & SI: $02(5.12 \%)$ & OI: $07(17.94 \%)$ & AI: $26(66.66 \%)$ & ABS: $02(5.12 \%)$ \\
\hline \multicolumn{5}{|c|}{ 2. Reading of Science Fictional materials } \\
\hline NI: $13(33.33 \%)$ & SI: $09(23.1 \%)$ & OI: $09(23.1 \%)$ & AI: $05(12.82 \%)$ & ABS: $03(7.7 \%)$ \\
\hline \multicolumn{5}{|c|}{ 3. Reading of literary texts that relate to students' course of study (recommended literary texts) } \\
\hline NI: $0(0 \%)$ & SI: $04(10.3 \%)$ & OI: $04(10.3 \%)$ & AI: $28(71.8 \%)$ & ABS: $03(7.7 \%)$ \\
\hline \multicolumn{5}{|c|}{$\begin{array}{l}\text { 4. Reading of literary texts not related to students' course of study, but for the beauty of the materials } \\
\text { vocabulary development }\end{array}$} \\
\hline NI: $03(7.7 \%)$ & SI: $07(17.94 \%)$ & OI: $15(38.5 \%)$ & AI: $12(30.8 \%)$ & ABS: $02(5.12 \%)$ \\
\hline \multicolumn{5}{|c|}{ 5. Regular reading of periodicals (e.g newspapers, magazines, short stories, etc) } \\
\hline NI: $04(10.3 \%)$ & SI: $05(12.82 \%)$ & OI: $13(33.33 \%)$ & AI: $14(35.9 \%)$ & ABS: $03(7.7 \%)$ \\
\hline \multicolumn{5}{|c|}{$\begin{array}{l}\text { 6. Reading of inspiring stories of distinguished personalities (autobiographies, biographies, diaries an } \\
\text { memoirs, etc) }\end{array}$} \\
\hline NI: 07 (17.94\%) & SI: $04(10.3 \%)$ & OI: $07(17.94 \%)$ & AI: $19(48.71 \%)$ & ABS: $02(5.12 \%)$ \\
\hline $29(12.4 \%)$ & $31(13.25 \%)$ & $55(23.50 \%)$ & $104(44.44 \%)$ & $15(6.41 \%)$ \\
\hline
\end{tabular}

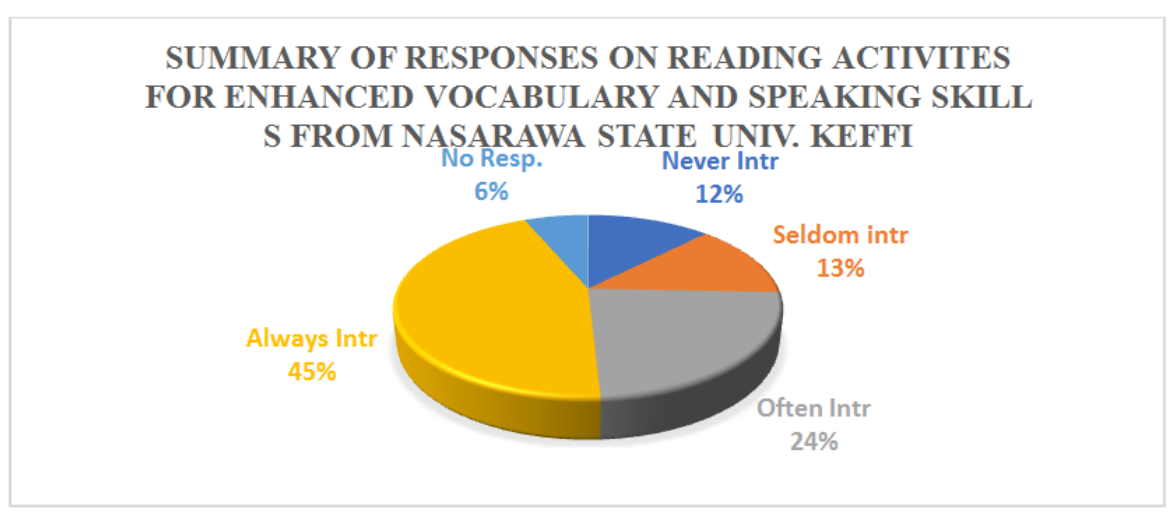

The responses from Nasarawa State University Keffi indicated that $45 \%$ and $24 \%$ of respondents chose always and often introduced options respectively. This shows that students from this part are likely to be proficient in terms of communicative competence. This is because reading helps learners to acquire a large repertoire of vocabularies, which assists in the attainment of good communicative competence. 


\begin{tabular}{|c|c|c|c|c|}
\hline \multicolumn{5}{|c|}{ Summary of Part One (1) } \\
\hline Never Introduced (NI) & Seldom Introduced & Often Introduced & Always Introduced & ABS: when no choice is made \\
\hline $\begin{array}{l}206 / 1,134 * 100= \\
18.17 \%\end{array}$ & $\begin{array}{l}228 / 1,134 * 100= \\
20.11 \%\end{array}$ & $\begin{array}{l}273 / 1,134 * 100= \\
24.07 \%\end{array}$ & $\begin{array}{l}369 / 1,134 * 100= \\
32.54 \%\end{array}$ & $58 / 1,134 * 100=5.11 \%$ \\
\hline
\end{tabular}
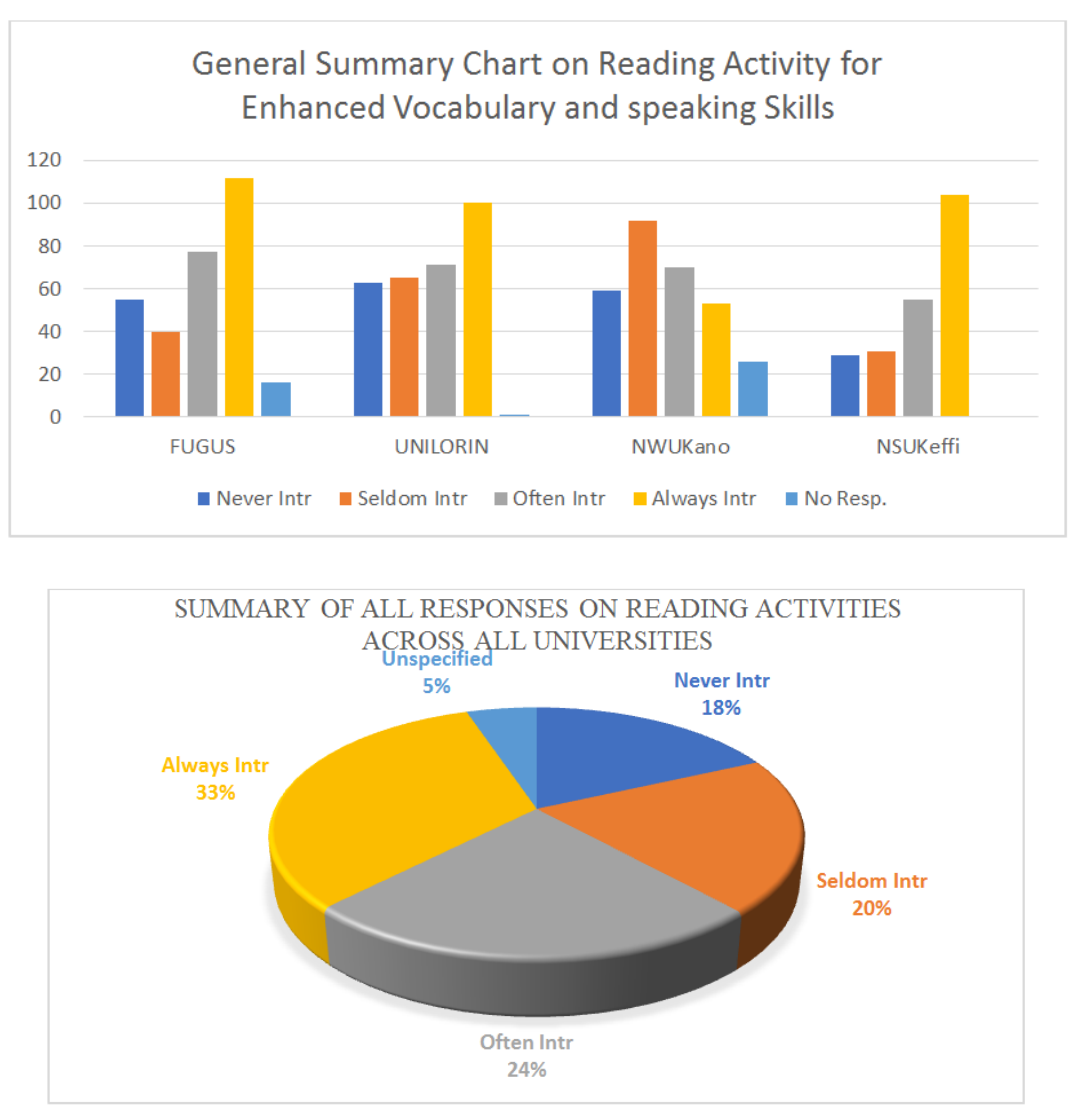

The overall data shows that students that testify to the fact that they always engage in the reading activities across all universities are higher than any other response. By this response, it is expected that students should portray a promising proficiency in the communicative aspect of the English language, failure to do that, however, would indicate that the responses did not reflect what is truly on the ground. Because, reading as many scholars hypothesized, increases an individual's capacity and efficiency.

\section{Part Two (2) Any Conscious Activity that Helps Boost Students' Speaking Ability}

Below is a summary of all responses to the six questions in this part (part four (4) from the different universities where questionnaires were distributed. The universities are Federal University Gusau, Zamfara State; University of Ilorin, Kwara State; Northwest University Kano; Kano State, and Nasarawa State University, Lafia, Nasarawa State. The total responses for each part are 300, so calculating the percentage will be done with that figure.

Federal University Gusau (FUGUS), Zamfara State

1. Making a conscious effort to speak in public even with mistakes

\begin{tabular}{|c|c|c|c|c|}
\hline NI: $10(20 \%)$ & SI: $04(8 \%)$ & OI: $05(10 \%)$ & AI: $29(58 \%)$ & ABS: $02(4 \%)$ \\
\hline \multicolumn{5}{|c|}{ 2. Extensive reading of grammar books or any other book that could polish your English Language } \\
\hline NI: $07(14 \%)$ & SI: $03(6 \%)$ & OI: $10(20 \%)$ & AI: $28(56 \%)$ & ABS: 02 (4\%) \\
\hline \multicolumn{5}{|c|}{ 3. Listening to native speakers or good orators as they speak by attending conferences, workshops or symposia, etc } \\
\hline NI: $08(16 \%)$ & SI: $13(26 \%)$ & OI: $10(20 \%)$ & AI: $16(32 \%)$ & ABS: $03(6 \%)$ \\
\hline \multicolumn{5}{|c|}{ 4. Watching English movies that could enhance your speaking skills } \\
\hline NI: $04(8 \%)$ & SI: $04(8 \%)$ & OI: $13(26 \%)$ & AI: $26(52 \%)$ & ABS: $03(6 \%)$ \\
\hline \multicolumn{5}{|c|}{ 5. Reading of English fictional novels which enhances students' vocabulary, hence, speaking ability } \\
\hline NI: $08(16)$ & SI: $01(2 \%)$ & OI: $18(36 \%)$ & AI: $21(42 \%)$ & ABS: $02(4 \%)$ \\
\hline \multicolumn{5}{|c|}{ 6. Attending any lecture that could coach/guide students on how to develop their speaking skills } \\
\hline NI: $10(20 \%)$ & SI: $04(8 \%)$ & OI: $11(22 \%)$ & AI: $23(46 \%)$ & ABS: 02 (4\%) \\
\hline $47(15.67 \%)$ & $29(9.67 \%)$ & $67(22.33 \%)$ & $143(47.67 \%)$ & $14(4.67 \%)$ \\
\hline
\end{tabular}




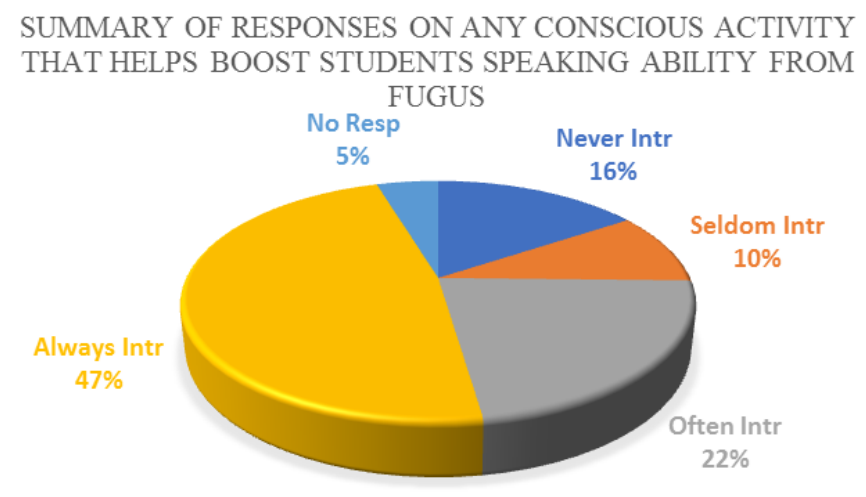

In FUGUS, as in the previous category, the response shows that $47 \%$ of the respondents indicate that they always engaged in some activities that could boost their speaking habits. Additionally, 22\% also indicated that they often engaged in various activities that could enhance their communicative abilities. This response, if truly is a reflection of what is happening with these respondents, indicates that the students from this part would have a near-perfect English language proficiency. This is based on Carnagie [13] beliefs that the chief cause of fear to speak in public simply is that one is not accustomed to speaking in public. Likewise, Krashen in his theory of the second language hypothesized that the over-use of a monitor in language learning (that is refusal to use the language for fear of mistake) leads to imperfection in the use of language.

University of Ilorin

\begin{tabular}{|c|c|c|c|c|}
\hline NI: $15(30 \%)$ & SI: $10(20 \%)$ & OI: $14(28 \%)$ & AI: $11(22 \%)$ & ABS: 0 \\
\hline \multicolumn{5}{|c|}{ 2. Extensive reading of grammar books or any other book that could polish your English Language } \\
\hline NI: $02(4 \%)$ & SI: $21(42 \%)$ & OI: $12(24 \%)$ & AI: $15(30 \%)$ & ABS: 0 \\
\hline \multicolumn{5}{|c|}{ 3. Listening to native speakers or good orators as they speak by attending conferences, workshops or symposia, et } \\
\hline NI: $14(28 \%)$ & SI: $13(26 \%)$ & OI: $14(28 \%)$ & AI: $09(18 \%)$ & ABS: 0 \\
\hline \multicolumn{5}{|c|}{ 4. Watching English movies that could enhance your speaking skills } \\
\hline NI: $07(14 \%)$ & SI: $17(34 \%)$ & OI: $08(16 \%)$ & AI: $18(36 \%)$ & ABS: 0 \\
\hline \multicolumn{5}{|c|}{ 5. Reading of English fictional novels which enhances students' vocabulary, hence, speaking ability } \\
\hline NI: $09(\mathbf{1 8 \%})$ & SI: $12(24 \%)$ & OI: $12(24 \%)$ & AI: $17(34 \%)$ & ABS: 0 \\
\hline \multicolumn{5}{|c|}{ 6. Attending any lecture that could coach/guide students on how to develop their speaking skills } \\
\hline NI: $12(24 \%)$ & SI: $12(24 \%)$ & OI: $14(28 \%)$ & AI: $12(24 \%)$ & ABS: 0 \\
\hline $59(19.67 \%)$ & $85(28.33 \%)$ & $74(24.67 \%)$ & $82(27.33 \%)$ & о \\
\hline
\end{tabular}

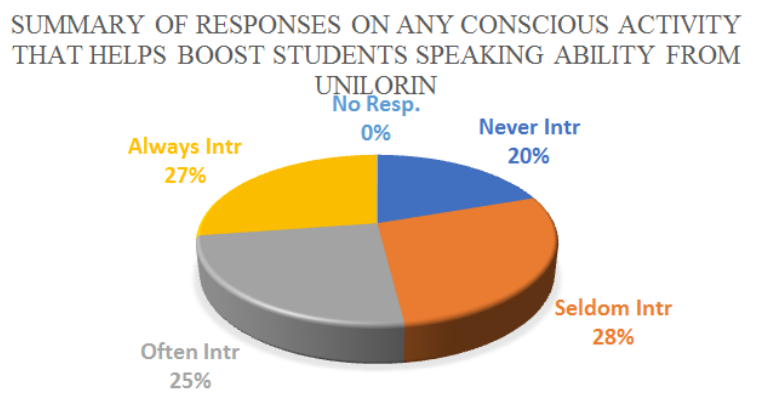

At the University of Ilorin, the data shows that respondents who testify that they seldom and always engaged in activities that could boost their speaking capacity top the remaining responses with $28 \%$ and $27 \%$ respectively. They were closely followed by the remaining two options, often $25 \%$ and Never $20 \%$. This shows that while some students engaged in such activities, some do not. In these parts, there will be students who could be proficient in terms of their speaking capacity, there were others who could not. This stand is supported by the Interactional Hypothesis by Michael Long (1996) which postulates that comprehensive input which is needed in language learning is more likely to occur under social interaction. 


\section{North-West University Kano}

1. Making a conscious effort to speak in public even with mistakes

\begin{tabular}{|c|c|c|c|c|}
\hline NI: $27(54 \%)$ & SI: $06(12 \%)$ & OI: $10(20 \%)$ & AI: $04(8 \%)$ & ABS: $03(6 \%)$ \\
\hline \multicolumn{5}{|c|}{ 2. Extensive reading of grammar books or any other book that could polish your English Language } \\
\hline NI: $08(16 \%)$ & SI: $17(34 \%)$ & OI: $16(32 \%)$ & AI: $06(12 \%)$ & ABS: $03(6 \%)$ \\
\hline \multicolumn{5}{|c|}{ 3. Listening to native speakers or good orators as they speak by attending conferences, workshops or symposia, etc } \\
\hline NI: $07(14 \%)$ & SI: $18(36 \%)$ & OI: $16(32 \%)$ & AI: $06(12 \%)$ & ABS: $03(6 \%)$ \\
\hline \multicolumn{5}{|c|}{ 4. Watching English movies that could enhance your speaking skills } \\
\hline NI: $09(18 \%)$ & SI: $16(32 \%)$ & OI: $10(20 \%)$ & AI: $09(18 \%)$ & ABS: $06(12 \%)$ \\
\hline \multicolumn{5}{|c|}{ 5. Reading of English fictional novels which enhances students' vocabulary, hence, speaking ability } \\
\hline NI: $05(10 \%)$ & SI: $15(30 \%)$ & OI: $21(42 \%)$ & AI: $06(12 \%)$ & ABS: $03(6 \%)$ \\
\hline \multicolumn{5}{|c|}{ 6. Attending any lecture that could coach/guide students on how to develop their speaking skills } \\
\hline NI: $05(10 \%)$ & SI: $09(18 \%)$ & OI: $18(36 \%)$ & AI: $15(30 \%)$ & ABS: $03(6 \%)$ \\
\hline $61(20.33 \%)$ & $81(27 \%)$ & $91(30.33 \%)$ & $46(15.33 \%)$ & $21(7 \%)$ \\
\hline
\end{tabular}

SUMMARY OF RESPONSES ON ANY CONSCIOUS ACTIVITY THAT HELPS BOOST STUDENTS SPEAKING ABILITY FROM NORTH-WEST UNIVERSITY KANO

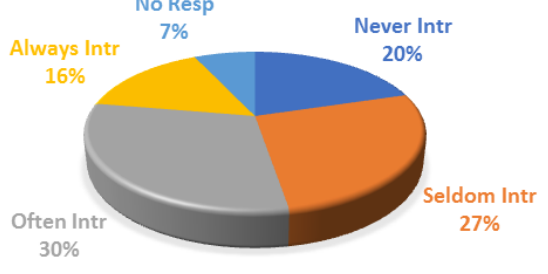

The response from North-West University Kano shows respondents who testify that they often engaged in activities that could boost their speaking habit lead with $30 \%$ followed by those that testify that those activities seldom take place with $27 \%$. The response indicates that while those activities do take place in this part, but it is never always. Based on this data, there tend to be students who may have a fair level of proficiency in the communicative aspect.

Nasarawa State University, Keffi

1. Making a conscious effort to speak in public even with mistakes

\begin{tabular}{|c|c|c|c|c|}
\hline NI: $05(12.82 \%)$ & SI: $07(17.94 \%)$ & OI: $12(30.8 \%)$ & AI: $14(35.9 \%)$ & ABS: $01(2.6 \%)$ \\
\hline \multicolumn{5}{|c|}{ 2. Extensive reading of grammar books or any other book that could polish your English Language } \\
\hline NI: $02(5.12 \%)$ & SI: $06(15.4 \%)$ & OI: $12(30.8 \%)$ & AI: $18(46.2 \%)$ & ABS: $01(2.6 \%)$ \\
\hline \multicolumn{5}{|c|}{ 3. Listening to native speakers or good orators as they speak by attending conferences, workshops or symposia, etc } \\
\hline NI: $04(10.25 \%)$ & SI: $06(15.4 \%)$ & OI: $13(33.33 \%)$ & AI: $15(38.5 \%)$ & ABS: $01(2.6 \%)$ \\
\hline \multicolumn{5}{|c|}{ 4. Watching English movies that could enhance your speaking skills } \\
\hline NI: $01(2.6 \%)$ & SI: $03(7.7 \%)$ & OI:05 (12.82\%) & AI: $25(64.10 \%)$ & ABS:05 (12.82\%) \\
\hline \multicolumn{5}{|c|}{ 5. Reading of English fictional novels which enhances students' vocabulary, hence, speaking ability } \\
\hline NI: $01(2.6 \%)$ & SI: $06(15.4 \%)$ & OI: $12(30.8 \%)$ & AI: $19(48.71 \%)$ & ABS: 01() $2.6 \%$ \\
\hline \multicolumn{5}{|c|}{ 6. Attending any lecture that could coach/guide students on how to develop their speaking skills } \\
\hline NI: $02(5.12 \%)$ & SI: $06(15.4 \%)$ & OI: $12(30.8 \%)$ & AI: $18(46.2 \%)$ & ABS: $01(2.6 \%)$ \\
\hline $15(6.41 \%)$ & $34(14.52 \%)$ & $66(28.20 \%)$ & $109(46.6 \%)$ & $10(4.3 \%)$ \\
\hline
\end{tabular}


The response from Nasarawa State University Keffi shows $47 \%$ of the respondents testify that they engaged in activities that could boost their communicative capacity in the English Language always. This is followed by those that indicated that they do engage in such activities often $28 \%$. The responses, based on Krashen's monitor theory and also Michael Long's Interactive hypothesis, would give rise to students who are proficient in terms of communicative aspects in the English Language.

\begin{tabular}{|c|c|c|c|c|}
\hline \multicolumn{5}{|c|}{ Summary of Part four (2) } \\
\hline $\begin{array}{l}\text { Never Introduced } \\
\text { (NI) }\end{array}$ & $\begin{array}{l}\text { Seldom } \\
\text { Introduced }\end{array}$ & $\begin{array}{l}\text { Often } \\
\text { Introduced }\end{array}$ & $\begin{array}{l}\text { Always } \\
\text { Introduced }\end{array}$ & $\begin{array}{l}\text { ABS: when no choice } \\
\text { is made }\end{array}$ \\
\hline $\begin{array}{l}182 / 1,134 * 100= \\
16.05 \%\end{array}$ & $\begin{array}{l}229 / 1,134 * 100= \\
20.19 \%\end{array}$ & $\begin{array}{l}298 / 1,134 * 100= \\
26.28 \%\end{array}$ & $\begin{array}{l}380 / 1,134 * 100= \\
33.51 \%\end{array}$ & $45 / 1,134 * 100=3.97 \%$ \\
\hline
\end{tabular}

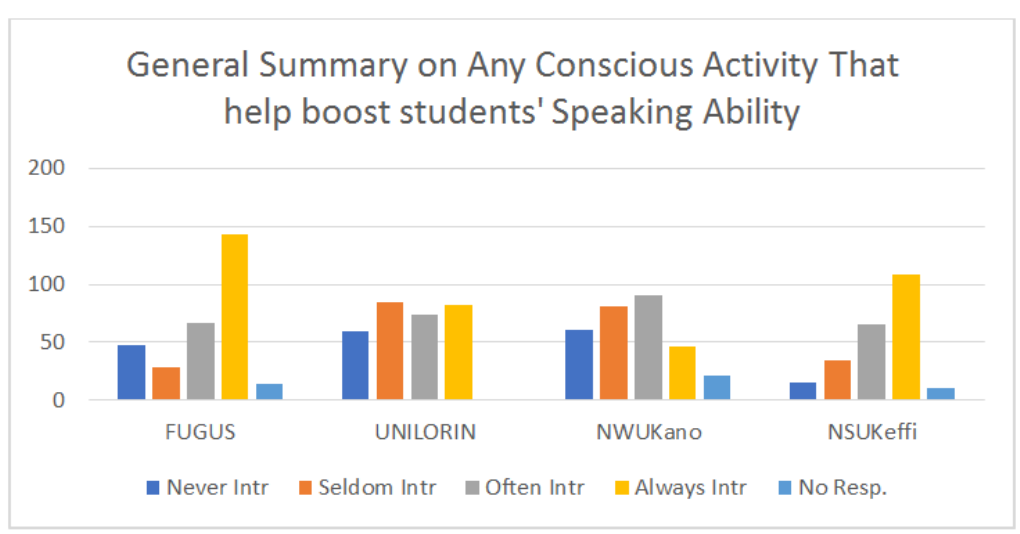

\section{CONCLUSION}

Communicative competence is an integral aspect of English Language learning. To attain success in one's study, a good grasp of both oral and written communication cannot be neglected by students. The research has established the fact that there are loopholes in the encouragement of oral activities that could improve students' performance in speaking abilities and enhance communicative competence. Many scholars like Yano [34], Brown [35], assert that successful language use for communication presupposes the development of communicative competence in the users of that language and that could only be achieved in an environment that supports the learner to speak the language frequently and imbibe a good reading culture for the development of his vocabularies. Michael Long [31] also in his Interaction Hypothesis states that the development of Language Proficiency is promoted by face-to-face interaction and communication.

\section{RECOMMENDATION}

The paper thus proposes the following recommendations:
1. That the student should be encouraged to read wide because extensive reading enhances vocabulary development which is a necessary tool for oral and written communication.

2. Language teachers should assist learners by bringing oral activities that require students to speak even when they make mistakes. This is of the position of many scholars that "the chief cause of fear to speak in public simply is that one is not accustomed to speaking in public".

3. The communicative approach which emphasize not just grammatical knowledge but also oral and written skills should be adopted by English teachers in the L2 classroom.

\section{Appendix (2) Questinnaire}

(1) Please indicate on the scale below $(\sqrt{ })$ whether you are introduced to reading (especially reading literary texts and text on subject areas) which could enhance students' speaking prowess. Reading helps students increase their vocabulary, having enough vocabulary will, in turn, boost their speaking ability.

\begin{tabular}{|c|c|c|c|c|c|}
\hline $\mathbf{S} / \mathbf{N}$ & Reading Activities that could enhance students' vocabulary as well as speaking ability & $\begin{array}{l}1 \\
\text { NI }\end{array}$ & $\begin{array}{l}2 \\
\text { SI }\end{array}$ & $\begin{array}{ll}\text { OI } \\
\end{array}$ & $\begin{array}{l}4 \\
\text { AI }\end{array}$ \\
\hline 1 & Reading of books related to the subject area (e.g sciences, history, Literature, English, etc) & & & & \\
\hline 2 & Reading of Science fictional materials & & & & \\
\hline 3 & Reading of Literary texts that relate to students' course of study (recommended literary texts) & & & & \\
\hline 4 & $\begin{array}{l}\text { Reading of literary texts not related to students' course of study, but for the beauty of the materials or } \\
\text { vocabulary development }\end{array}$ & & & & \\
\hline 5 & Regular reading of periodical materials (e.g newspaper, magazines short stories, etc) & & & & \\
\hline 6 & $\begin{array}{l}\text { Reading of inspiring stories of distinguished personalities (e.g autobiographies, biographies, diaries, } \\
\text { memoirs, etc) }\end{array}$ & & & & \\
\hline
\end{tabular}


1. Never Introduced (NI) 2. Seldom introduced (SI) 4. Often Introduced (OI) 3. Always Introduced (AI)

(2) Please indicate on the scale below $(\sqrt{ })$ whether you engaged or are engaging in any activity that could boost your selfdevelopment as well as your speaking ability.

\begin{tabular}{|l|l|l|l|l|l|}
\hline S/N & Any conscious activity that helps boost students' speaking habit & $\mathbf{1}$ & $\mathbf{2}$ & $\mathbf{3}$ & $\mathbf{4}$ \\
NI & OI & AI \\
\hline 1 & Making a conscious effort to speak in public even if you make mistakes & & & \\
\hline 2 & Extensive reading of grammar books or any other book that could polish your English language & & & \\
\hline 3 & $\begin{array}{l}\text { Listening to a native speaker or good speakers as they speak by attending any conference, } \\
\text { workshop or symposia, etc }\end{array}$ & & & \\
\hline 4 & Watching English movies that could enhance your speaking skills & & & & \\
\hline 5 & Reading of English fictional novels which enhances students' vocabulary, hence, speaking ability & & & \\
\hline 6 & Attending any lecture that could coach/guide students on how to develop their speaking skill & & & \\
\hline
\end{tabular}

Keywords: 1. Never Introduced (NI) 2. Seldom introduced (SI) 4. Often Introduced (OI) 3. Always Introduced (AI)

\section{REFERENCES}

1. Moody, H. L. B. (1970). Varieties of English: Practice in Advanced Uses of English. London: Longman.

2. Hedge, T. (2008). Teaching and learning in the language classroom, China: Oxford University Press.

3. Waandja, I. (2014). 'Investigating Factors leading to Speaking Difficulties in English as a Second Language among Grade 5 learners'. retrieved on the $20^{\text {th }} \quad$ June, 2018 at www.academia.edu/7259651/investigating_factors _leading_to_speaking_difficulties_in_English_am ong_grade_5_learners/php

4. Savignon, S. J. (2011). Communicative Language Teaching: Linguistic Theory and Classroom Practicee $^{e}$ www.gigapedia.com. Web: 28 December 2011.

5. Van Ek, J. A. (1976). Significance of the Threshold Level in the Early Teaching of Modern Languages. Strasbourg: Council of Europe, 1976.

6. Eyisi, J. (2004). Common Errors in the Use of English. Second Edition. Onitsha: African First.

7. Baldeh, F. (1990). Better English Language Learning and Teaching. Nsukka: Fulladu.

8. Opara, E. C., Abdel-Rahman, E., Soliman, S., Kamel, W. A., Souka, S., Lowe, J. E., \& AbdelAleem, S. (1999). Depletion of total antioxidant capacity in type 2 diabetes. Metabolism, 48(11), 1414-1417.

9. Yano, C. R., \& Yano, C. R. (2003). Tears of longing: Nostalgia and the nation in Japanese popular song (Vol. 206). Harvard Univ Asia Center.

10. Canale, M., Swain, M. (1980). 'Theoretical bases of communicative approaches to second language teaching and testing.' Applied Linguistics.

11. Widdowson, H. G. (1983). Learning Purpose and Language Use. Oxford: Oxford University Press.

12. Urrutia, M., \& Vega, H. (2010). 'Encouraging Teenagers to improve Speaking Skills Through Games in a Colombian Public Schools'. Profile 12(1), 2010. Bogota, Colombia.
13. Carnegie, D. (1962). The quick and easy way to effective speaking, New York: Association press.

14. Wallace, C. (1992). Reading. Oxford: Oxford University Press.

15. Willie, E. (2009). Reading Culture and Value Reorientation. In Readership promotion and National Development: A collection of papers presented at the 7 th Nigeria International Book Fair and National Book Fairs Lagos: The Nigeria Book Fair Trust.

16. Oyewole, O. (2017). Impact of Reading Culture Amongst Selected Secondary Schools in Owo Local Government Area in Ondo State, Nigeria. In Developing Countries Studies, 7(10):88-101.

17. Unoh, S. (1995). Studies on Reading in English. Ibadan.

18. Ogbonna, I. M. (2014). Books, libraries and reading in the digital age. Enugu: Eminota Publishers.

19. Chomsky, N. (1965). Aspects of the Theory of Syntax. Cambridge, Mass.: MIT Press.

20. Hymes, D. (1972). On Communicative Competence $^{\text {ee }}$ Eds. J.B. Pride and J. Holmes. Sociolinguistics: $\quad$ Selected Readings. Harmondsworth: Pengiun, 269-293.

21. Pillar, G. M. (2014). A Framework for Testing Communicative Competence. University College of Nyiregyhaza, Hungry. Grandenpillar Chotmain.com. retrieved on 21st February.

22. Krashen, S. D. (1987). Principles and Practice in Second Language Acquisition. Prentice-Hall International.

23. Dulay \& Burt. (1974). "Natural Sequences in Child Second Language Acquisition." Language Learning, 24(1): 37-53.

24. Fathman, A. (1975). The relationship between age and second language productive ability. Language learning, 25(2), 245-253.

25. Makino, S., Kunimoto, K., Muraoka, Y., Mizushima, Y., KATAGIRI, K., \& TOCHINO, Y. (1980). Breeding of a non-obese, diabetic strain of mice. Experimental Animals, 29(1), 1-13. 
26. Krashen, S. D. (1988). Second Language Acquisition and Second Language Learning. Prentice-Hall International.

27. Selinker, L. (1972). "Interlanguage". International Review of Applied Linguistics Vol 10 No 4 PP. 209-241.

28. Corder, S. P. (1967). The significance of learner's errors.

29. Odlin, T. (1989). Language transfer (Vol. 27). Cambridge: Cambridge University Press.

30. Brunner, H. R., Gavras, H., Laragh, J. H., \& Keenan, R. (1973). Angiotensin-II blockade in man by sar1-ala8-angiotensin II for understanding and treatment of high blood-pressure. The Lancet, 302(7837), 1045-1048.

31. Long, M. (1996). The Role of Environment in Second Language Acquisition in Ritchie, William; Bhatia, Tej (eds). The Handbook of Second
Language Acquisition. San Diego: Academic Press, 413-468.

32. Swain, M., \& Lapskin, S. (1995). Problem in Output and Cognitive Processes they Generate: A step Towards Second Language Learning. Applied Linguistics. 16: 371-391.

33. Odiba, I. A. (2005). "Planning the Nigeria education system for the Challenge of globalization": A paper presented at the first Annual conference of the faculty of arts \& humanities: Kogi State University Anyigba.

34. Yano, Y. (1999). 'What is it to Learn a Foreign Language?: Non-native Speaker English in the Twenty first Century'. Second Language Research.

35. Brown, H. (1994). Teaching by Principles: An Interactive Approach to Language Pedagogy. Englwood Cliffs, NJ: Prentice Hall regents. 